\title{
Teaching autonomy: turning the teaching evaluation of the Applied Optics course from impart knowledge to the new intelligent thinking
}

Huifu Zhao, Yu Chen, Dongmei Liu

Huifu Zhao, Yu Chen, Dongmei Liu, "Teaching autonomy: turning the teaching evaluation of the Applied Optics course from impart knowledge to the new intelligent thinking," Proc. SPIE 10452, 14th Conference on Education and Training in Optics and Photonics: ETOP 2017, 104523Y (16 August 2017); doi: $10.1117 / 12.2265361$

SDIE Event: 14th Conference on Education and Training in Optics and Photonics, ETOP 2017, 2017, Hangzhou, China 


\title{
"Teaching autonomy" - Turning the teaching evaluation of the Applied Optics course from impart knowledge to the new intelligent thinking
}

\author{
( School of Opto-Electronic Engineering, Changchun University of Science and Technology,
}

Changchun, Jilin, china 130022)

\section{Huifu Zhao Yu Chen Dongmei Liu}

\begin{abstract}
There is a saying that "The teacher, proselytizes instructs dispels doubt." Traditional teaching methods, constantly let the students learn the knowledge in order to pursue the knowledge of a solid grasp, then assess the teaching result by evaluating of the degree of knowledge and memory. This approach cannot mobilize the enthusiasm of students to learn, and hinders the development of innovative thinking of students. And this assessment results have no practical significance, decoupling from practical application. As we all know, the course of Applied Optics is based on abstract theory. If the same teaching methods using for this course by such a "duck", it is unable to mobilize students' learning initiative, and then students' study results will be affected by passive acceptance of knowledge. How to take the initiative to acquire knowledge in the class to the students, and fully mobilize the initiative of students and to explore the potential of students, finally evaluation contents more research on the practical significance? Scholars continue to innovate teaching methods, as well as teaching evaluation indicators, the best teaching effect to promote the development of students. Therefore, this paper puts forward a set of teaching evaluation model of teaching autonomy.

This so-called "autonomous teaching" is that teachers put forward the request or arrange the task and students complete the learning content in the form of a group to discuss learning before the lesson, and to complete the task of the layout, then teachers accept of students' learning achievements and answer questions. Every task is designed to evaluate the effectiveness of teaching. Every lesson should be combined with the progress of science and technology frontier of Applied Optics, let students understand the relationship between research and application in the future, mobilize the students interest in learning, training ability, learn to take the initiative to explore, team cooperation ability. As well, it has practical significance to every evaluation, making the teaching to active learning in teaching, cultivating students' creative potential, deep, solid foundation for the day after learning work.
\end{abstract}

\footnotetext{
14th Conference on Education and Training in Optics and Photonics: ETOP 2017, edited by Xu Liu, Xi-Cheng Zhang, Proc. of SPIE Vol. 10452, 104523Y · C 2017 ICO, IEEE, OSA, SPIE CCC code: $0277-786 X / 17 / \$ 18 \cdot$ doi: $10.1117 / 12.2265361$
} 
Key words: Applied optics; Teaching autonomy; Education evaluation

\section{Introduction}

Applied Optics is an important professional basic course in optoelectronic information engineering that has a very strong theory and emphasizes practical application. It plays a very important role in cultivating talents of optoelectronic information engineering. "Focusing on talent cultivation and taking reform and innovation as the motive force, improving the quality of higher education at all levels" is the key of the Chinese education development and education reform in recent years, while curriculum construction is the most important and basic section in comprehensive reform. With the deepening of teaching reform, a variety of teaching methods have been applied to the teaching of applied optics, but the current teaching of Applied Optics is that teachers gush out, explain hardly, while the silent students attend lectures in a passive way, lack of their own views and the exploration out of interest. The results of this teaching could cause the lost of the personality of students and strangle the creative talent of students.so facing the status of this education, we need to explore new educational methods to enable students to learn in a more positive way, totally master the theory of Applied Optical, bring it to the future research work authentically and become the talents of optics

\section{Teaching autonomy}

The current society is information-based, knowledge-based society, each person's role in society is diverse and dynamic. The future of work and study is not only to adapt to competition, but also to learn how to cooperate. For their own development, everyone needs self-learning, the ability and quality of self-improvement. Mentioned in the "2003-2007 Education Revitalization Plan" issued by the Ministry of Education in 2004, the aim of university autonomy containing "democratic governance, scientific decision-making, sound leadership and democratic supervision" is the academic freedom. In the Applied Optics teaching, autonomous teaching also reflects the spirit of university autonomy, the Applied Optics teaching autonomy is to enable students to become masters of learning, less dependent on others to help their own effective learning which is a comprehensive ability. "Whether a black cat or a white cat, a good cat catches mice" no matter what way students adopt to learn knowledge, the students really master the knowledge as the ultimate assessment goals, to enable students to study autonomously, self-care, exert students initiative, students The contents of the teaching content take the initiative to seize the inner links between the knowledge points, so that students a comprehensive understanding of the core issues, through the selection of content and optimization of the curriculum system, students optical thinking, and in practice can be flexible use. All learning that can effectively 
promote students' development should be autonomous learning, and the true cooperative learning and inquiry learning are autonomous learning too. However, "autonomous learning" has no ready experience, no established model and needs slow infiltration to gradually formed during the course of continuous exploration.

\section{The exploration of Applied Optics teaching autonomy}

Autonomous learning is a comprehensive ability which mainly include the following factors, the methods and skills of independent study (including collecting information, analysis, recording and collation of information); the habits of independent learning; the ability of doing small and simple exploratory and confirmatory experiment. The the course of Applied Optics includes much content, the teaching effect is highly dependent on the teaching method, the teaching reform requires stressing the focal point of Applied Optics and the teaching methods need to make adjustments to follow it.

1) The teaching design

Teachers in the pre-semester sort out the content for students to learn individually, what content for competitive learning, which content for cooperative learning according to teaching objectives design teaching context, respectively. In a word, the curriculum design should reflect student learning personality. Students are the cognitive main part of learning. The learning process is the process of students' exploring, discovering problems and constructing meaning. Therefore, we should attach importance to the role of students as the main cognitive, reflecting the characteristics of individual learning and the learning initiative that students exert while studying. At the same time, it is found that students' academic achievement is positively related to each other in cooperative learning. that is, when a student reaches his learning goal, other students can achieve learning goals. In cooperative learning, we should pay attention to the design of two types of cooperation and consultation:

A: The cooperation between Students and students. This is the key to cooperation, students' interaction depends on the following factors of the design, the question or task brought up, the return of the group status, the group's condition, the interactive skills.

B: The cooperation between teachers and students. Teachers guide, help and promote students' learning as the leading figure in the learning process.

\section{2) Exploratory teaching}

College students' thinking and psychology are more mature with a strong desire to explore and deal with the problem. Teachers can combine the teaching content and guide students to identify problems which allow students to access information, summarize the analysis, find a 
solution. It make student master knowledge to mobilize the students interest in learning in their involvement.

3) Seminar teaching

To explore and research-based interaction between teachers and students is teaching and develop students' cognitive and research ability research-based teaching is a theme-based teaching. Mainly in the application of optical related academic topics, If teachers and students in the class establish a link and pay attention to guide students interest-oriented, we can go beyond the limitations of the book knowledge, contact with academic frontier more intimately and explore the unknown world of fun And methods. Teachers and students are equal in this kind of seminar teaching class which will contact teachers with students together tightly so that they can comprehend the true meaning of science.

\section{A: teaching security}

The college set up a special seminar to teach the organization to manage the entire seminar teaching system. To ensure the enthusiasm of each student's lectures through the credit system.

B: topics selected

As each teacher's energy is limited, It needs to take into account the topic when fully consider the people-oriented in the whole course of Applied Optics. According to their interests and the topics of interest the college that student choose, teachers should be sure to reflect the cutting-edge content of the subject area to ensure the quality of the theme. Reflecting the essence of the field and cutting-edge thinking, the topic can be not mature theory to inspire students to think independently, resulting in unique insights. The students will be able to experience and experience different teachers in different topics. In the course of different subjects, students will have a lot of extra-curricular activities after class. Not only mastered the basic knowledge of applied optics, and through in-depth independent thinking, harmonious teamwork, we can learn from each other in cooperation, and even cross-disciplinary seminars, through this series of mutual Contact the seminar, so that students are no longer passive acceptance of knowledge, but to take the initiative to explore knowledge and create knowledge. During the close contact between teachers and students in the seminar, teachers and students share the process of discovery of scientific achievements and the experience and fun with each other, cultivate the spirit of collaboration, team awareness, critical thinking and expression and thinking skills Which let Students in the future of academic work can be more stringent, keep truth first and love life more so that they can use knowledge that we learn in school in future.

4) Flip the class

Flip the class is the role of teachers and students are interchangeable, so that students can be the class master, the teacher works as a guide. In the design of the contents of the reverse class 
must not be too difficult, very basic content, so that students can form groups through the group Together to make lesson plans and demonstrate in class. In order to ensure that students master the knowledge, after the end of the course, the teacher will let the students test the content of class learning which can be a innovative way. For example, before the exam, the test will be made into a WeChat version, and then generate two-dimensional code, after-school students can scan the two-dimensional code to answer. In order to prevent students from copying each other, you can set the answer time to ensure the test results. Timely feedback of the students can appraise the degree they mastered in the class, while the scores of class tests can be used as usual results, together with the total score after school which will ensure the enthusiasm of students to learn.

\section{5) Academic display}

Unlike the real presentation of research paper, the academic display is a platform for students to present themselves or their team's small inventions, small creations, or small experiments on the basis of their previous competitions, inventions, and creations. Through the establishment of this platform, on the one hand is the idea of the positive creation of students to encourage, on the other hand for other students also have inspired the effect which is similar to the academic wall function platform. In fact, it is the most basic for students the to test the degree they mastered on Applied Optics which will cultivate students' scientific research ability in the undergraduate stage and rigorous quality of study, so it will lay a very good foundation for both future study and research.

\section{Teachers' qualification construction and teaching evaluation}

Excellent teachers can bring advanced educational concepts and teaching methods. In terms of teacher development, teachers are trained to solve the difficulties teachers face in class teaching through regular seminars, workshops, training sessions and luncheons so that teachers can master the teaching concepts, teaching methods and class organization in order to break through the current undergraduate education which doesn't have enough broad field, the teaching with a single development bottleneck. In Harvard, teachers' teaching effectiveness and teaching evaluation become the necessary conditions for teachers to promote tenure. For teachers, excellence in teaching and academic research have the same importance. But the current evaluation system of our country is heavy in scientific research and light in teaching, which greatly influences the enthusiasm of teaching. To change this phenomenon, we must reform the current evaluation system of teaching reform and create a good atmosphere of attention to undergraduate education.

\section{Analysis of the Applied Optics autonomy reaching model}

Applied Optics is a very basic and important specialized course for the students in the faculty of Optoelectronics Information Engineering. Students' subjective initiative is the key factor in 
determining the teaching effect of this course. All teaching models that can inspire the enthusiasm of students are worth trying, the above-mentioned methods are based on student-centered teaching reform to arouse students' learning initiative furthest.

\section{References:}

[1] Liu Yandong's speech on the work conference of comprehensive improvement of Higher Education Quality.

[2] The declared relevant documents of 2012 years "national boutique resource sharing course". 